\title{
Dekalog historyka, czyli drogi i bezdroża dziejopisarstwa Marka Cetwińskiego
}

(Rec.: Marek Cetwiński, Drogi i bezdroża dziejopisarstwa, Studio AB, Olsztyn 2017, ss. 456)

I was dostrzegłem, o dumni badacze, Gdy wami burza jak śmieciem pomiata, Zamknięci w sobie, jak w konchy ślimacze, Chcieliście, mali, obejrzeć krąg świata.

Konieczność - rzekli - wedle ślepej woli Panuje światu, jako księżyc morzu. A drudzy rzekli: Przypadek swawoli W ludziach, jak wiatry w nadziemskim przestworzu.

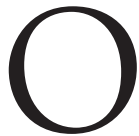
statnia książka Marka Cetwińskiego, zatytułowana Drogi $i$ bezdroża dziejopisarstwa (2017), stanowi zbiór tekstów, które latami ukazywały się w periodykach o niszowych nakładach oraz które zostały wygłoszone jako referaty na różnych

*Wydział Filologiczno-Historyczny, Instytut Historii, Zakład Metodologii Historii i Historii Historiografii, e-mail: a.czerniecka-haberko@ajd.czest.pl.

** Wydział Filologiczno-Historyczny, Instytut Historii, Zakład Metodologii Historii i Historii Historiografii, e-mail: tadeusz.srogosz@ajd.czest.pl.

${ }^{1}$ http://literat.ug.edu.pl/amwiersz/0057.htm (dostęp: 21 I 2018). 
sympozjach. Autor podkreślił, że stanowi ona kontynuację dwóch wcześniejszych publikacji, czyli Ideologii i poznania ${ }^{2}$ oraz Metamorfoz śląskich ${ }^{3}$. Historyk pisał bowiem, że ksiażka ta: „kontynuuje [...] wattki obecne w "Ideologii i poznaniu" oraz "Metamorfozach śląskich". Głównie ten mówiący o wpływie otaczającej autorów "teraźniejszości» na przedstawiana przez nich wizję przeszłości. O tym więc, jak te obrazy przeszłości sa próbą rozwiązania nader współczesnych historykom problemów przebranych zaledwie w historyczne kostiumy. Opowieści ("narracje») historyczne ucza nas czegoś o przeszłości, ale głównie jest to przeszłość samych historyków oraz epoki, w której to oni, a nie ich bohaterowie, żyli. I tak praca o średniowieczu napisana w XIX wieku jest przede wszystkim świadectwem kultury tego właśnie, XIX wieku, a nie średniowiecza. Mówi wszak o tym, jak i dlaczego ówczesny badacz interpretował "rzeczy dawne» - tę jedyną dostępna naszemu poznaniu, bo wciąż obecna, formę przeszłości. Obecność owych "rzeczy dawnych» - zabytków i tradycji - wyznacza, przynajmniej powinna wyznaczać, granice interpretacyjnej swobody historyków. Nie tylko więc historycy kształtują "przeszłość", ale i ona sama wpływa na historyków. Przeszłość i teraźniejszość wciąż wzajemnie na siebie oddziałują. Zmieniająca się "teraźniejszość" zmienia kolejnym pokoleniom wizje przeszłości a te $z$ kolei pozwalają inaczej spojrzeć na nurtujące ich problemy współczesności. Między przeszłością i teraźniejszością toczy się nieustająca gra zmieniająca jedną i druga”" (s. 7).

Drogi $i$ bezdroża składaja się z Przedmowy oraz sześciu części. Pierwsza $z$ nich została zatytułowana Przeszłość gra ambicji i wyobraźni. Zaprezentowano w niej piśmiennictwo poprzedzające powstanie historii jako nowoczesnej nauki. Marek Cetwiński zaznaczył, że ta powstała w Polsce w XIX w. Historyk pisał: „w XIX wiek historiografia polska wchodziła $z$ całym bagażem przekonań typowych dla kultury agrarnej, ksenofobicznym podziałem na "swoich" i "obcych", przekonaniem o moralnej wyższości ludzi utrzymujacych się $z$ rolnictwa nad "zepsutymi" mieszkańcami wielkich miast zajmujących się przemysłem i handlem. O ile dla historyków żyjących w społecznościach wielkomiejskich (ich symbolem jest twórczość i recepcja Tukidydesa i Machiavellego) sprzeczności stanowia pro-

${ }^{2}$ M. Cetwiński, Ideologia i poznanie: społeczne funkcje mediewistyki ślaskiej po 1945 roku, Częstochowa 1993.

${ }^{3}$ I d e m, Metamorfozy śląskie: studia źródłoznawcze i historiograficzne, Częstochowa 2002. 
blem do rozwiązania $z$ korzyścią całej społeczności, to u nas - wzorem naszych wymarłych połabskich pobratymców - sa powodem do wykluczenia ze wspólnoty wszystkich inaczej myślących. Narzucana jednomyślność to znakomita gleba dla uprawy konformizmu i hipokryzji. Skłonność do przemilczania różnic, nieumiejętność przekonywania i dyskusji to także spadek po kulturze agrarnej” (s. 9).

Historiografia polska była zatem efektem wstrzasu, który został wywołany przez likwidację Rzeczpospolitej Obojga Narodów. Wstrząs ten spowodował poszukiwanie przyczyn upadku szlacheckiego państwa. Stąd też historiografię polska - zdaniem Autora - opanowała „zmora przeszłości” (s. 7-9).

Zmora przeszłości to tytuł kolejnej części recenzowanej publikacji. Ten rozdział pracy przedstawia dysharmonię między oficjalna historia a prywatna pamięcią. Historię należało bowiem „dopasować do obowiazujących wykładni oficjalnej historii, do aprobowanych przed chwilą większości społeczeństwa wzorów osobowych" (s. 9-10).

Część trzecia woluminu została zatytułowana Górny Śląsk - margines historii czy historiografii? Zdaniem M. Cetwińskiego Górny Śląsk „zajmuje w historiografii miejsce nie odpowiadajace jego rzeczywistej roli w najnowszych dziejach Polski [...]. Tkwiąca w okowach kultury agrarnej historiografia polska długo nie była w stanie prawidłowo rozeznać tutejszej historii, ani też dobrać narzędzi badawczych odpowiednich do badań społeczeństwa epoki industrialnej" (s. 10).

Rozdział czwarty, zatytułowany Historie zwykłych ludzi, zawiera przede wszystkim refleksje metodologiczne Autora. Zawiera również opisy „warunków życia zwykłych ludzi”. Ich nawyki bowiem „określaja nieraz bieg wydarzeń politycznych" (s. 10-11).

Część piąta, Historycy, to niezwykle ciekawy rozdział, gdyż zawiera analizę politycznego zaangażowania polityków. Marek Cetwiński pisał: „stopień politycznego zaangażowania historyków bywa różny. Niektórzy zadowalają się samym tylko prawdopodobieństwem głoszonych hipotez inni, niestety mniej liczni, dążą do ustalenia ściśle udokumentowanych faktów. W części poświęconej historykom wyraźnie preferuję tych rygorystycznie przestrzegających zasad surowej krytyki wiarygodności źródeł informacji. Poczet rozpoczyna Zorian Dołęga Chodakowski, autor, który wywarł znaczący wpływ na polski romantyzm. Mylił się on wprawdzie straszliwie w kreślonym przez siebie obrazie zamierzchłych dziejów Słowian, niemniej 
jednak to on wskazał na potrzebę posiłkowania się w badaniach historycznych także wynikami nauk pokrewnych: językoznawstwa, etnografii, archeologii, religioznawstwa. Nie powinna też dziwić obecność tu Napoleona Bonapartego, którego uwagi świadczą o wzrastającym w pierwszej ćwierci XIX stulecia krytycznym podejściu do historycznych przekazów. Uczonym, który kładł podwaliny pod nowoczesny warsztat badawczy, był Gustaw Adolf Harald Stenzel. On też - niekoniecznie $z$ własnego wyboru - stał się nauczycielem historyków polskich. Zapomniany dziś Wilhelm Bogusławski jako pierwszy $z$ naszych historyków rozważał wpływ środowiska przyrodniczego na dzieje społeczeństwa. Josef Pekař, olbrzym czeskiej historiografii i miłośnik poezji Adama Mickiewicza, otwiera natomiast szereg badaczy uznajacych prymat kultury nad polityką. Mariaż polityki $z$ historią może - pod warunkiem jednak, że ta pierwsza nie przytłoczy tej drugiej - okazać się nader korzystny. Wskazuja na to zarówno niektóre prace pisane w latach powojennych zawirowań ideologicznych, jak i autobiografia Karola Modzelewskiego" (s. 11-12).

Część szósta została zatytułowana Zakończenie. Mimo tak sugestywnego tytułu, konwencjonalnym zakończeniem ona nie jest. Część tę stanowi bowiem tekst pt. Jakiej historiografii potrzeba dziś $w$ Polsce? To zatem odpowiedź Autora na pytanie postawione $\mathrm{w}$ jego tytule. Dlatego też badacz pisze: „przede wszystkim takiej, która upowszechnia ucząc zasad warsztatu historycznego, wiedzę o sposobach oceny wiarygodności wszelkiej docierającej do nas informacji. Także takiej, która wolna od nacjonalizmu będzie zbliżać ludzi różnych kultur. Pozwoli poznać i zrozumieć "Innych". Powinno to zatem być więcej historii społecznej i kulturowej. Mniej zaś uprawianej w nacjonalistycznym duchu historii politycznej i militarnej. Słowem - potrzebna jest nam - historykom i czytelnikom - "kultura historyczna" a nie koniunkturalna $z$ reguły "polityka historyczna" (s. 12).

Drogi $i$ bezdroża to tom, który nie tylko stanowi rozliczenie ze współczesnym sposobem postrzegania badań historycznych (np. budowanie hipotezy na hipotezie czy też niebezpieczeństwa $z$ nadużywania metafor), ale równocześnie wskazuje kierunek, w którym powinny one podążać. Marek Cetwiński pisał bowiem: „współczesna historiografia polska powinna zatem być mniej etnocentryczna, w żadnym zaś wypadku ksenofobiczna. Nie powinna łudzić czytelników wizją bezkonfliktowej rzekomo wspólnoty naro- 
dowej. Nie powinna też jednak konfliktów tych podsycać narzucając "jedynie słusznie" poglądy na dzieje Polski i świata. Powinna natomiast przekazywać nie tylko wiedzę faktograficzna ale także - może nawet przede wszystkim - wiedzę o sposobach ustalania tych faktów. Powinna, jak dawno już ujał Lukian $z$ Samosat, przedstawiać "zdrowy sad $w$ sprawach politycznych i zdolność wyrażania się" aby myśl była "zwarta $i$ ścisła" (s. 456).

Owych sześć części stanowi próbę uzasadnienia przesłanek skłaniających ludzi do fascynacji przeszłością. Historia fascynuje bowiem różne grupy społeczne i zawodowe. Adoruja ja zarówno uczeni, jak i amatorzy. Autor podkreślił, że książka „jest [...] próba przedstawienia powodów skłaniających ludzi do zajmowania się przeszłością. Jakich poszukiwali dróg aby ja poznać oraz dlaczego tak często zbaczali na bezdroża. Także o tym, jakich używali argumentów aby przekonać czytelników do swych, nieraz mocno dyskusyjnych wizji. Słowem - dlaczego przeszłość tak bardzo fascynuje zarówno polityków, uczonych i licznych amatorów spośród ludzi przeciętnych" (s. 7).

Drogi $i$ bezdroża to praca, która pozornie dotyczy jednostki. W publikacji odnajdziemy bowiem teksty poświęcone m.in. Mistrzowi Wincentemu, Janowi Długoszowi, Bartoszowi Paprockiemu, Henrykowi Samsonowiczowi, Jerzemu Strzelczykowi, Karolowi Modzelewskiemu. Jednak to tylko fasada tej książki, gdyż głębsza nad nią refleksja pozwoli wywnioskować, że odnajdziemy w niej bohatera zbiorowego, którym jesteśmy my sami, czyli współcześni historycy. Stąd też praca stanowi manifest historyka do historyków. Odezwa ta jest poparta latami pracy zawodowej. Zatem to przesłanie doświadczonego/świadomego badacza. Historyka, o którym Marceli Antoniewicz pisał: „doświadczenia zdobyte na wielu polach badawczych, zwłaszcza wciąż pogłębiane refleksje źródłoznawcze, inspirowały do przemyśleń dotyczących metodologii badań historycznych, w szczególności na gruncie mediewistyki i genealogii, ale także zaniedbań w krytycznym podejściu do źródeł historycznym w znacznie szerszym planie. Profesor Marek Cetwiński opublikował szereg zwięzłych, ale bardzo ważkich tekstów, które $z$ czasem zyskuja na znaczeniu. Wspomnijmy tylko rozważane $O$ kłopotach $z$ metodologia historii $w$ ostatniej dekadzie tysiaclecia, O kłamstwie historiograficznym w pozamoralnym sensie czy publikację Potężniejszy od Boga? Historyk a granice naukowego poznania przeszłości. $\mathrm{Na}$ osobne odnotowanie zasługuje tekst pt. Metodologii genealogii 
zarys krytyczny, który można polecić każdemu badaczowi podejmującemu badania genealogiczne, jeśli tylko mają one zmierzać do konkluzji o randze naukowej. Zresztą większość publikacji, które wyszły spod pióra Marka Cetwińskiego zawiera refleksje nawiąujace do epistemologii historii i - co istotne - mocno usadowione sa przy tym na gruncie źródeł historycznych"4.

Należy wyeksponować, że dla M. Cetwińskiego „historia jest [...] heureza, krytyką i interpretacja zachowanych świadectw przeszłości. Wynika $z$ tego, że przeszłości badać nie można jeśli nie istnieje ona, jak określa to św. Augustyn, w teraźniejszości pod postacią dawnych rzeczy. Traktując historię jako wiedzę o przeszłości liczyć się zatem należy $z$ tym, że na wiele pytań $z$ braku współczesnych badanym wydarzeniom źródeł odpowiedzieć po prostu nie możemy. Nie możemy, historyk bowiem wobec milczenia źródeł nie ma nic do roboty.

Wielu jednak autorów $z$ tym pogodzić się nie chce. Snują więc rozmaite domysły, zwane dla powagi hipotezami, aby wskazać, iż coś w przeszłości wydarzyć się mogło. Zatraca się wtedy granica między historią, czyli tym, co się rzeczywiście niegdyś wydarzyło a poezja, czyli tym, co się tylko mogło zdarzyć. Typowym przykładem pisarzy historycznych i najbardziej chyba dziś znanym $z$ tych, którzy za Franciszkiem Piekosińskim moga o sobie powiedzieć: "podpisany tymczasem przepada za hipotezami, bo natura horret vacuum: gdzie więc tylko ukazuje się na tle dziejów naszych ciemna dziura. Tę podpisany zalepia zaraz hipotezowym obrazem", jest Karol Modzelewski" .

Alternatywę takiego sposobu myślenia stanowia niemal wszystkie publikacje M. Cetwińskiego. Jest on bowiem historykiem, który zawsze podkreśla, że tylko źródła historyczne gwarantuja poznanie przeszłości ${ }^{6}$. Historykiem, który podstawowym elementem swojej pracy uczynił źródło. Zatem historykiem, który wszystkie swoje publikacje opiera na precyzyjnie dobranej i rzetelnie opracowanej bazie źródłowej. Drogi i bezdroża to praca, która stanowi kontynuację już wcześniej obranej drogi. To publikacja będąca gloryfikacją źródła historycznego.

${ }^{4}$ M. Antoniewicz, Stuga Klio - Profesor Marek Cetwiński, [w:] Klio viae et invia. Opuscula Marco Cetwiński dedicata, red. A. Odrzywolska-Kidawa, Warszawa 2010, s. XIV-XV.

${ }^{5}$ M. Cetwińs ki, Ideologia i poznanie..., s. 97.

${ }^{6}$ Ibidem. Vide: S. Kościałkowski, Historyka. Wstęp do studiów historycznych, Londyn 1954, s. 23. 
Marek Cetwiński ma jednak świadomość, że źródło jest tylko nośnikiem informacji. Stąd też z całą świadomością akcentuje, że historyk jako zawodowy, profesjonalny badacz przeszłości nie może zapomnieć, by poddać źródło skomplikowanym zabiegom zmierzającym do ustalenia stopnia jego wiarygodności ${ }^{7}$. Dlatego też pisał: „historyk zobowiąany jest sprawdzić wiadomość zanim uzna ja za wiarygodna, czyli potwierdzona przez inny niezależny przekaz. Niezależny to znaczy taki, który nie tylko opiera się na innych niż pierwszy źródeł informacji, ale nie ma też w nim "wspólnego, identycznego podłoża ideowego i psychicznego" i wyrasta $z$ odmiennej atmosfery. Wiedza o sposobach krytyki wiarygodności może bez wątpienia być przydatna także przy odbiorze wiadomości podawanych przez media. A tym, jak poucza powszednie doświadczenie, chęć manipulacji nie jest obca. Nie warto, więc im bezgranicznie ufać. Wskazany natomiast jest krytyczny do nich stosunek. Niebezpieczeństwo przyjęci optyki źródła - komunikatu podawanego przez środki masowego przekazu - grozi wprawdzie także historykowi, ale "staje się najważniejszy zagrożeniem dla człowieka bez studiów historycznych". Pozbawiony umiejętności krytyki źródłowej czytelnik przyjmuje wątpliwej wartości za dobra monetę, buduje sobie na tej podstawie fałszywy obraz wydarzeń $\mathrm{i}-\mathrm{w}$ rezultacie - feruje wyroki moralne i przyjmuje postawy polityczne zgodne $z$ oczekiwaniami manipulatora. Atakowany [...] człowiek właśnie w wiedzy o metodach historycznej analizy, w stosowanych przez historyka sposobach sprawdzania wiarygodności i autentyczności źródeł informacji, może znaleźć narzędzia skutecznie chroniące go przed ewentualną manipulacją. Stale, więc powinna historiografia przypominać pytania, jakie Joachim Lelewel nakazywał stawiać źródłom informacji: 1) czy autor źródła chce mówić prawdę, czy nie?, 2) Jeśli chce, to czy wolno mu ją mówić, czy też ktoś lub coś mu tego wzbrania?, 3) Czy zdolność umysłu, uczucia lub namiętności pozwalają mu przekazać prawdę?, 4) Czy musiał obawiać się czegokolwiek w wypadku wykrycia jego kłamstwa?" (s. 449-450) ${ }^{8}$.

Autor recenzowanej pracy podkreśla, że historycy nie zawsze w sposób wystarczający znają osiągnięcia wcześniejszych pokoleń.

${ }^{7}$ M. Cetwiński, Drogi i bezdroża..., s. 449. Vide: J. Topolski, Metodologia historii, Warszawa 1984; id em, Jak się pisze i rozumie historię. Tajemnice narracji historycznej, Warszawa 1998; idem, Wprowadzenie do historii, Poznań 2001.

8 Vide: H. Ki e reśs, Humanistyka, [w:] Powszechna encyklopedia filozofii, Polskie Towarzystwo Tomasza z Akwinu, http://www.ptta.pl/pef/pdf/h/Humanistyka.pdf (dostęp: 14 VI 2018). 
Pozbawiają się zatem możliwości korzystania $z$ ich osiagnięć. Zachłystują się różnymi kierunkami tzw. nowoczesnej historiografii. Należy jednak podkreślić, że wiele $z$ nich funkcjonowało w piśmiennictwie historycznym znacznie wcześniej, np. historyczne opisy życia. Pole badawcze historii społecznej, jak wskazał George Macaulay Trevelyan: „powszednie życie mieszkańców kraju w minionych wiekach: obejmuje ono zarówno osobiste, jak gospodarcze stosunki wzajemne między różnymi warstwami, charakter rodziny i życia domowego, warunki pracy i odpoczynku, stosunek człowieka do przyrody, kulturę każdej epoki, która wyrasta $z$ tych ogólnych warunków życia i przybiera coraz to inne kształty w życiu religijnym, literaturze i muzyce, w architekturze, nauce i sposobie myślenia" . Stąd też w historiografii polskiej XIX i XX w. odnajdziemy wiele prac opisujących życie codzienne. Należy jednak podkreślić, że ich autorzy używali w swoich narracjach innej aparatury pojęciowej oraz innych założeń metodologicznych ${ }^{10}$. Niemniej jednak np. Jan Stanisław Bystroń wprost jeden $z$ rozdziałów poświęcił życiu wojskowemu, w którym znalazły miejsce m.in. takie zagadnienia, jak: dyscyplina wojskowa, życie obozowe, wierzenia i zabobony, duszpasterstwo wojskowe, służba lekarska, sądownictwo ${ }^{11}$.

Marek Cetwiński przedstawił życie codzienne jako zagadnienie historiograficzne, zagadnienie rozwijajace się od opisu obyczajów do antropologii historycznej ${ }^{12}$. Według tegoż Autora na długo przed Fernandem Braudelem „struktury codzienności” wyznaczały granice tego, co „możliwe i niemożliwe” w realizacji politycznych zamierzeń. W konkluzji napisał: „badanie struktur codzienności- przypomnijmy - to dziś antropologia historyczna $z$ typowym dla niej zamiłowaniem do mikrohistorii, analizą niewielkich społeczności, często zmarginalizowanych przez modernizacyjne procesy i pozostajacych $\mathrm{w}$ konflikcie $z$ głównymi tendencjami epoki. Paradoksalnie to właśnie ta konfliktowość sprzyja głębszemu poznaniu kultury dominującej. Dzieje się tak $z$ tego prostego faktu, iż to właśnie konflikt jest źródłotwórczy. Stąd zamiłowanie przedstawicieli antropologii

${ }^{9}$ G.M. Trevelyan, Historia społeczna Anglii od Chaucera do Wiktorii, tłum. A. Klimowicz, Warszawa 1961, s. 15-16.

${ }^{10}$ Niektórym z nich, np. Witoldowi Kuli (por. W. Piasek, Antropologizowanie historii. Studium metodologiczne twórczości Witolda Kuli, Poznań 2004), przypisuje się nawet później wyartykułowane koncepcje.

11 J.S. Bystroń, Dzieje obyczajów w dawnej Polsce, t. II (Wiek XVI-XVIII), Warszawa 1976, s. 347-390.

${ }^{12}$ M. Cetwińs ki, Drogi i bezdroża..., s. 252-260. 
historycznej do analizowania akt sądowych" (s. 258). Taki punkt widzenia pozwala określić zarówno kulturę dominującą, jak i kulturę grup podporządkowanych, czy wręcz kontestujacych wartości dominujące. Krytycy zarzucaja przedstawicielom antropologii historycznej konstruowanie kronik policyjnych. Wydaje się jednak, że argumenty krytyków sa zbyt daleko idace, ponieważ antropologia historyczna to nie tylko analiza akt sadowych ${ }^{13}$.

Autor omawianej publikacji podkreśla użyteczność historii. Wskazuje, że „to [...] metody dochodzenia do prawdy, zasady ustalania wiarygodności źródła - a nie, jak się potocznie przyjmuje, szczegółowa wiedza o bliższej czy zamierzchłej nieraz przeszłości - sa tym, co zwykłemu obywatelowi potrzebne jest w codziennej praktyce" (s. 451). Zatem puentę niniejszego tekstu może stanowić teza sformułowana przez Hugo Steinhausa, umieszczona w przedmowie do pracy pt. Kalejdoskop matematyczny. Steinhaus pisał: „Jaka jest teza tej książki? Sa dwie:

1. przedmiotem matematyki jest rzeczywistość,

2. matematyka jest uniwersalna: nie ma rzeczy, która by była jej obca"14.

Parafrazując te słowa, można wskazać, że tezy pracy M. Cetwińskiego sa dwie:

1. przedmiotem historii jest rzeczywistość,

2. historia jest uniwersalna, nie ma rzeczy, która by była jej obca.

\section{Bibliografia}

\section{OpRacowania}

Antoniewicz M., Stuga Klio - Profesor Marek Cetwiński, [w:] Klio viae et invia. Opuscula Marco Cetwiński dedicata, red. A. Odrzywolska-Kidawa, Warszawa 2010.

Bystroń J.S., Dzieje obyczajów w dawnej Polsce, t. II (Wiek XVI-XVIII), Warszawa 1976.

Cetwiński M., Drogi i bezdroża dziejopisarstwa, Olsztyn 2017.

Cetwiński M., Ideologia i poznanie: społeczne funkcje mediewistyki ślaskiej po 1945 roku, Częstochowa 1993.

13 Ibidem, s. 258.

${ }^{14}$ https://slynne-cytaty.pl/autorzy/hugo-steinhaus/ (dostęp: 7 II 2018). 
Cetwiński M., Metamorfozy śląskie: studia źródłoznawcze i historiograficzne, Częstochowa 2002.

Kościałkowski S., Historyka. Wstęp do studiów historycznych, Londyn 1954.

Piasek W., Antropologizowanie historii. Studium metodologiczne twórczości Witolda Kuli, Poznań 2004.

Topolski J., Jak sie pisze i rozumie historię. Tajemnice narracji historycznej, Warszawa 1998.

Topolski J., Metodologia historii, Warszawa 1984.

Topolski J., Wprowadzenie do historii, Poznań 2001.

Trevelyan G.M., Historia społeczna Anglii od Chaucera do Wiktorii, tłum. A. Klimowicz, Warszawa 1961.

\section{Netografia}

http:/ /iterat.ug.edu.pl/amwiersz/0057.htm (dostęp: 21 I 2018).

https://slynne-cytaty.pl/autorzy/hugo-steinhaus/ (dostęp: 7 II 2018).

Kiereś H., Humanistyka, [w:] Powszechna encyklopedia filozofii, Polskie Towarzystwo Tomasza z Akwinu, http://www.ptta.pl/pef/pdf/h/Humanistyka.pdf (dostęp: 14 VI 2018). 